\title{
Effectiveness of Bioactive Combinations of Several Plant Substances to Inhibit the Growth of Escherichia coli and Salmonella sp.
}

\author{
Pasaribu T, Sinurat AP, Wina E, Purwadaria T, Haryati T, Susana IWR \\ Indonesian Research Institute for Animal Production. PO Box 221, Bogor 16002, Indonesia \\ E-mail: pasaributiurma@yahoo.com
}

(received 13-08-2018; revised 05-09-2018; accepted 20-09-2018)

\begin{abstract}
ABSTRAK
Pasaribu T, Sinurat AP, Wina E, Purwadaria T, Haryati T, Susana IWR. 2018. Efektifitas campuran bahan bioaktif beberapa tanaman dalam menghambat pertumbuhan bakteri Escericia coli dan Salmonella sp. JITV 23(3): 112-122. DOI: http://dx.doi.org/10.14334/jitv.v23i3.1851

Antibiotik imbuhan pakan (AGP) telah dilarang penggunaannya sebagai pakan tambahan di berbagai negara, sehingga diperlukan penggantinya. Sebuah penelitian in vitro telah dilakukan untuk mempelajari potensi kombinasi beberapa ekstrak tanaman dalam mencegah pertumbuhan bakteri pathogen yang secara alami terjadi pada saluran gastrointestinal unggas dan in vivo untuk mengevaluasi populasi E. coli dalam ileum, respon imun dan profil darah ayam. Campuran bioaktif ketiga tanaman (asap cair dari cangkang Anacardium occidentaleor CLS, ektrak tanaman Phyllanthun niruti L.(EM) dan ekstrak Synzygium aromaticum extract (EDC) diformulasikan dan dievaluasi kefektifannya dalam menghambat pertumbuhan bakteri Escericia coli dan Salmonela sp. secara in vitro. Campuran (KE) tersebut kemudian dilarutkan dalam tiga konsentrasi yang berbeda, yaitu: 100\%KE; 50\%KE dan 25\%KE yang kemudian diamati kefektifannya dalam menghambat pertumbuhan E. coli dan Salmonella sp. menggunakan metode microplate reader. Dalam uji biologis, kombinasi bioaktif adalah pada konsentrasi 0,0625\% CAM + 0,0625\% EM + 0,0313\% EDC. Perlakuan terdiri dari 8 jenis ransum, masing-masing terdiri dari 2 ulangan dan setiap ulangan terdiri dari 5 DOC. Pada akhir percobaan (35 hari), darah diambil dari 2 ekor ayam pada setiap replikasi. Hasil penelitian menunjukkan bahwa semakin tinggi konsentrasi campuran bioaktif (KE100), semakin tinggi pula kemampuannya dalam menghambat pertumbuhan bakteri E. coli dan Salmonella sp.. Campuran bahan bioaktif CAM, EM dan EDC lebih efektif dibandingkan antibiotik Zn-bacitracin dalam menghambat pertumbuhan E. coli dan Salmonella sp.. Konsentrasi optimal KE dengan kefektifan serupa dengan AGP adalah 25\%. Dapat disimpulkan bahwa campuran CAM, EM dan EDC mampu menghambat partumbuhan bakteri E. coli dan bahkan mampu menghilangkan keberadaan bakteri Salmonella sp. Dalam pengukuran secara biologi, campuran CAM, EM dan EDC baik dalam bentuk ekstrak maupun bubuk dengan dosis tinggi, sedang maupun rendah tidak mempengaruhi bobot limfa, bursa fabricier dan profil darah. Campuran terbaik ekstrak CAM, EM dan EDC untuk menurunkan total populasi bakteri dan E. coli adalah dosis sedang yaitu 0,0625\% (ekstrat) dan 0,625\% (bubuk). Hal serupa juga berlaku pada penambahan bobot hidup pada penggunaan dosis bentuk ekstrak maupun bubuk yang tepat yang juga dapat menggantikan penggunaan antbiotik. Kombinasi CAM, EM dan EDC terbaik berpotensi sebagai pengganti AGP di dunia pakan unggas, khususnya ayam.
\end{abstract}

Kata Kunci: Anacardium occidentale, Phylanthus niruri L., Synzygium aromaticum, E. coli, Salmonella sp.

\section{ABSTRACT}

Pasaribu T, Sinurat AP, Wina E, Purwadaria T, Haryati T, Susana IWR. 2018 Effectiveness of bioactive combinations of several plant substances to inhibit the growth of Escherichia coli and Salmonella sp.. JITV 23(3): 112-122. DOI: http://dx.doi.org/10.14334/jitv.v23i3.1851

The use of antibiotic growth promoters (AGP) has been banned as feed additives in many countries, therefore the alternatives need to be found. An in vitro experiment was conducted to study the potential of combination of some plant extract to inhibit growth of pathogen bateria that normally occur in the poultry gastro intestinal tract and in vivo studies to evaluate the population of E. coli in the ileum, the immune response and blood profile of chicken. The combination of three plants bioactives (liquid smoke of cashew shells of Anacardium occidentaleor CLS, Phyllanthus niruri L. extract (EM), and Synzygium aromaticum extract (EDC) were formulated and evaluated for its effectiveness to inhibit growth of Escherichia coli and Salmonella sp. in vitro.The mixtures (KE) were then made in 3 different concentrations, i.e. $100 \% \mathrm{KE}$, 50\% KE, and 25\% KE and studied their effectiveness to inhibit growth of $E$. coli or Salmonella sp. using microplate reader method. In biological assay, the bioactive combination was at a concentration of $0.0625 \%$ CAM $+0.0625 \%$ EM $+0.0313 \%$ EDC. The treatment consisted of 8 types of rations, each of it 2 replications and each replication consisted of 5 DOC. At the end of the experiment (35 days), blood was taken from 2 chickens at each replication. The results showed that the higher the concentration of the bioactive combination (KE100) the higher the ability to inhibit the growth of E. coli or Salmonella sp. The combination of bioactive substances CAM, EM, and EDC more effectively than Zn-bacitracin antibiotics to inhibit the growth of E. coli and Salmonella sp. The optimum concentration of KE with the similar effectiveness as the AGP was $25 \%$. It was concluded that the combination of CAM, EM, and EDC was able to inhibit the growth of E. coli and even capable to eliminate the presence of Salmonella sp. In the biological assay, a combination of CAM, EM, and EDC either extract or powder form, high dose, medium or low does not 
affect the weight of the spleen, bursa fabricius, and blood profile. The best combination of CAM, EM, and EDC extracts to decreases the total bacterial population and E. coli was middle dose ie $0.0625 \%$ (extract) and $0.625 \%$ (powder). Likewise for live weight gain that was a good dose of extract or powder form can replace antibiotics. It was concluded that combinations of CAM, EM, and EDC had potential as a substitute for AGP in poultry feed, especially chickens.

Key Words: Anacardium occidentale, Phylanthus niruri L., Synzygium aromaticum, E. coli, Salmonella sp

\section{INTRODUCTION}

In general, antibiotic additives (AGPs / antibiotics growth promoters) are given to poultry by mixing them into feed or drinking water to increase production and prevent disease (Griggs \& Jacob 2005). Giving AGP aims to minimize and even to reduce the population of pathogenic microbes in the intestine so that the nutrients contained in the gut are more dominantly absorbed. Pathogenic bacteria commonly found in the digest tracts of chickens and humans are Escherichia coli and Salmonella spp. In chickens, the bacteria are eliminated/killed by giving antibiotic supplementation so that the growth of livestock can increase up to 5-6\% and the use of feed is more efficient up to 3-4\% (Butaye et al. 2003). However, the use of antibiotics in livestock such as chickens can cause bacterial resistance to antibiotics. For example, Campylobacter and Salmonella against fluoroquinolone antibiotics and the third generation cephalosporins which is a constraint to the use of antibiotics in livestock (Noor \& Poeloengan 2005). Many countries have banned the use of AGP, including Indonesia, as stated in Law No. 18 of 2009 juncto Law no. 14 of 2014. The ban on the use of antibiotics as a growth booster have been effective since January 1, 2018. Therefore, other materials such as AGP alternatives such as bioactive substances are needed. Several bioactive substances have been tested for their activity against pathogenic microbes in vivo (Lopez et al. 2012), but some are still in vitro test (Hoque et al. 2007).

Many local plants contain bioactive substances that function as antibacterial, antioxidant or antifungal such as cashew nut shells (Anacardium occidentale), meniran (Phyllanthus niruri L.), and clove leaf (Syzygium aromaticum). Several studies have been conducted for this purpose, such as the use of bioactive from Aloe vera, turmeric, Curcuma zanthorrhiza and Morinda citrifolia plants (Sinurat et al. 2004; Sinurat et al. 2009; Bintang et al. 2007).

Cashew (Anacardium occidentale) has pseudo-fruit waste and shell. When the shell extracted will be obtained liquid (oil) called biofat or Cashew Nut Shell liquid (CNSL). The waste of cashew nut shells is around $45-50 \%$, with production of 137,496 tons in 2016, cashew shells is obtained around 61.873268 .748 tons (SPI 2015-17). The bioindustry product of cashew nut shell consists of biofat, biosmoke and biochar
(Saenab et al. 2016). Of these products, biofat (CNSL) has been widely studied, while biosmoke and biochar products from cashew shells have not been studied. Biosmoke (liquid smoke) is the result of decomposition process of cashew shells after extracted using hexane. The pyrolysis process is carried out with high heat without oxygen initiated by combustion and followed by total or partial oxidation of the main product (Bridgwater 2004). Liquid smoke from cashew shells can reduce the amount of $E$. coli in vitro (Sinurat et al. 2018), and suppress the growth of Candida utilis (Pasaribu et al. 2017).

Phyllanthus niruri L. (meniran) is a wild herb that is easy to grow in various geography. P. niruri L. can cure gastrointestinal disorders, and diarrhea because the content of bioactive substances is antimicrobial (Setyohadi et al. 2011). The compounds contained in the $P$. niruri $L$. ie alkaloids $(0.122 \%)$, saponins (0.214\%), tannins (0.040\%), phenol (0.079\%), glycosides (0.090\%) (Gbadamosi et al. 2015). Water extract on meniran inhibits E. coli, Staphylococcus aureus, Salmonella typhi (Lestariningsih et al. 2015).

Syzygium aromaticum (cloves) contain the active compounds of phenol (eugenol, flavonoid, hydroxybenzoic acid, hydroxycinnamic acid and hydroxyphenyl propene (Cortés-Rojas et al 2014; Perez-Jiménez et al. (2010). Eugenol has been shown to have antifungal, antiseptic and insect repellents. Eugenol inhibits the growth of fungus by damaging the walls and permeability of cells resulting in impaired growth (Putri 2002). Clove water extract can inhibit the growth of Escherichia coli, Staphylococcus aureus and Bacillus cereus (Cortés-Rojas et al 2014).

Sinurat et al. (2018) have identified bioactive substances in 11 plants. Based on the results of the identification that liquid smoke from cashew nut shells (Anacardium occidentale) is potential as antibacterial, Phyllanthus niruri L.extract as an antioxidant, and clove leaf (Syzygium aromaticum) as an antifungal. With these three functions, it is hoped that the bioactive combination of the three plants has a higher inhibitory effect on the growth of E. coli and Salmonella sp.

This study aims to determine the inhibition power of the liquid smoke combination of cashew nut shells (Anacardium occidentale), Phyllanthus niruri L. extract and clove (Synzygium aromaticum) leaf extract on growth of Escherichia coli and Salmonella sp. in vitro as information for in vivo testing as a substitute for AGP in poultry. 


\section{MATERIALS AND METHODS}

\section{Preparation of extract and liquid smoke}

The making of Phyllanthus niruri L. or clove leaf extraction and preparation of cashew nut shells was done at the laboratory of Ciawi Bogor, Indonesian Research Institute for Animal Production. The preparation of meniran or clove leaf extraction was done by inserting 1 gram of powdered meniran or clove leaves into the test tube, added with $10 \mathrm{~mL}$ methanol $70 \%$, then put into ultrasonic for 30 minutes. Furthermore, centrifuged for 15 minutes at $2500 \mathrm{rpm}$, the top layer is taken with a pipette, this part is called as an extract of $P$. niruri L. (EM) or extract Syzygium aromaticum leaf (EDC). The production process of cashew shell liquid smoke was done in a small industry of liquid smoke and charcoal manufacture in Cinangneng Village, Bogor. Preparation of liquid smoke using cashew shells that have been previously extracted with hexane solution as described by Saenab et al. (2016).

\section{In vitro inhibitory test}

Test of inhibition of Escherichia coli and Salmonella sp carried out in the Laboratory of Microbiology Indonesian Research Institute for Animal Production (IRIAP) Bogor. E. coli and Salmonella sp used are collections of IRIAP cultures. Extracts of bioactive substances that have been prepared combined and observed for its effectiveness. The test dose refers to the optimum dose of each extract performed in vitro in the previous study (Sinurat et al. 2018). The test was done by microplate reader method to study the inhibitory power of bioactive substance, by inoculating E. coli or Salmonella sp into microplate which has 96 wells. Microplate reader is a tool to perform analysis of active compounds or microorganisms quickly based on turbidity measured with optical density (OD) using a spectrophotometer. The common detection modes measured in this tool are the absorbance and intensity of fluorescence (Petersen et al. 2014). Resistance to the growth of E. coli and Salmonella sp was observed by measuring the turbidity level on the microplate at a wavelength of $630 \mathrm{~nm}$.

\section{Preparation of microbial cultivation and plant bioactive substances}

Escherichia coli or Salmonella sp culture with a concentration of $108 \mathrm{CFU} / \mathrm{mL}$ bacteria was made through its turbidity setting at the absorbance of 0.138 using a spectrophotometer at $620 \mathrm{~nm}$ wavelength. The liquid smoke of cashew shells (CAM), meniran extract (EM), clove leaf extract (EDC), and bacitracin (Bac) before being used for an inhibitory test, were first filtered using a filter membrane with $0.45 \mu \mathrm{m}$ pores. CAM is made with a concentration of 0.25 by mixing 1 $\mathrm{mL}$ of pure CAM with $3 \mathrm{~mL}$ of aqueous. EM is made with a concentration of 0.25 by mixing $1 \mathrm{~mL}$ of pure EM with $3 \mathrm{~mL}$ of aqueous). EDC was made with a concentration of 0.125 by mixing $0.5 \mathrm{~mL}$ of pure EDC with $3.5 \mathrm{~mL}$ of aqueous. The three extracts were then mixed with a ratio of $1: 1: 1$ (100\%), i.e $1 \mathrm{ml}$ CAM + $1 \mathrm{ml} \mathrm{EM}+1 \mathrm{ml}$ EDC is called $100 \%$ extract combination (KE100). Then, this combination was made in three concentration levels with $50 \%$ dilution (KE50) and 25\% (KE25), by adding aquadest with a ratio of $1: 1$ and $1: 3$. As a comparison, a positive control $(\mathrm{K}+)$ is used $\mathrm{Zn}$-Bacitracin at a concentration of 250 ppm. Blank is made by mixing aqueous with nutrient broth medium (NBM) without E. coli or Salmonella sp bacteria in microplate reader wells. Negative control (K-) is made by adding bacteria in aqueous solution. For $\mathrm{K}+, \mathrm{K}$ - and other treatments, a well-filled nutrient broth medium was mixed with 140 $\mu \mathrm{L}$ bacteria.

In summary, the bacteria inhibitory treatment performed is as follows:

$\mathrm{B}=$ Blank $(60 \mu \mathrm{L}$ aquadest $+140 \mu \mathrm{L}$ nutrient broth media/NBM)

$\mathrm{K}_{-} \quad=\quad$ Negative control $(60 \mu \mathrm{L}$ aquadest +140 $\mu \mathrm{L}$ bacteria)

$\mathrm{K}+1=$ Positive control $(60 \mu \mathrm{L}$ bacitracin 250 ppm $+140 \mu \mathrm{L}$ bacteria)

$\mathrm{K}+2=$ Positive control $2(60 \mu \mathrm{L}$ bacitracin 500 ppm $+140 \mu \mathrm{L}$ bacteria)

$\mathrm{KE} 100 \mathrm{E}=$ Combination $\mathrm{KE} 100$ extract $(60 \mu \mathrm{L}$ $\mathrm{KE} 100+140 \mu \mathrm{L}$ E coli)

$\mathrm{KE50E}=$ Combination of KE50 extract $(60 \mu \mathrm{L}$ $\mathrm{KE} 50+140 \mu \mathrm{L}$ E coli)

$\mathrm{KE} 25 \mathrm{E}=$ Combination of KE25 extract $(60 \mu \mathrm{L}$ $\mathrm{KE} 25+140 \mu \mathrm{L}$ E coli)

KE100S $=$ Combination of KE100\% extract $(60 \mu \mathrm{L}$ $\mathrm{KE} 100+140 \mu \mathrm{L}$ Salmonella $\mathrm{sp})$

KE50S $=$ Combination of KE50 extract $(60 \mu \mathrm{L}$ $\mathrm{KE} 50+140 \mu \mathrm{L}$ Salmonella sp)

KE25S $=$ Combination of KE25 extract $(60 \mu \mathrm{L}$ $\mathrm{KE} 25+140 \mu \mathrm{L}$ Salmonella sp)

Data analysis was done by analyzing the pattern of Randomized Complete Design to compare the effect of treatment on the growth of E. coli and Salmonella sp.

This study has fulfilled the code of ethics no. Balitbangtan/Balitnak/A/ 03/2016. 
Table 1. Combination dosage of the smoke of cashew shells (CAM), meniran extract (EM), And clove leaf extract (EDC) to be tested

\begin{tabular}{lccc}
\hline \hline Combination type & A. occidentale (\%) & P. niruri L (\%) & S. aromaticum (\%) \\
\hline Extract : & 0.125 & 0.125 & 0.0625 \\
High dose & 0.0625 & 0.0625 & 0.0313 \\
Medium dose & 0.0313 & 0.0313 & 0.0157 \\
Low dose & & & 0.625 \\
Powder : & 0.125 & 1.25 & 0.313 \\
High dose & 0.625 & 0.625 & 0.157 \\
Medium dose & 0.313 & 0.313 & 0.05 \\
Low dose & 0.05 & 0.05 & 0 \\
Zn-Bacitracin & 0 & 0 & 0 \\
Negative control & & & \\
\hline
\end{tabular}

Exploration the effectiveness of combinations of bioactive substances in feed

Combination of plant bioactive: The combination of plant extracts consists of a combination of the liquid smoke of Anacardium occidentale (CAM) shell, Phyllanthus niruri L. (EM) extract, and Syzygium aromaticum leaf extract (EDC). A combination with various concentrations was conducted to test its effectiveness when mixed in the ration. Determination of concentration in ration was based on effective concentration to suppress E. coli and Salmonella sp growth in previous research in vitro, that is combination with concentration $0.0625 \%$ CAM $+0.0625 \%$ EM + $0.0313 \%$ EDC. For testing its effectiveness in vivo the concentration is increased twice for high doses and halved or to $50 \%$ for low doses. Testing the effectiveness of bioactive combination was also done using the powder form. The concentration of the ingredients in the form of flour uses the conversion 4 because $1 \mathrm{ml}$ of the extract is obtained from 4 grams of flour. However, the CAM is not in the form of powder. Thus, the amount of each extract and powder added in the ration is presented in Table 1 .

\section{Chicken and management}

Chicken used in this study was the broiler strain Ross maintained from day-old chick until 35 days. Feed and drinking water were given ad libitum. Chicken fed with the same composition, namely feed starter for 1-21 days old chickens and grower for chickens aged 22-35 days. The treatment consisted of 8 types of rations, each treatment consisted of 2 replications and each replication consisted of 5 DOCs. At the end of the experiment (35 days), blood was taken from 2 chickens on each replication. The basal ration composition was administered equally in all treatments, while the difference between treatments described with different levels of extract/powder combinations is described in Table 1. Body weight of the chicken weighed at the time of blood sampling (age 35 days). Then as much as 4 chickens from each treatment were euthanized to measure the weight of several internal organs (spleen and bursa fabricius). Intestinal contents were also taken for measuring the total amount of bacteria and the amount of $E$. coli. Calculation of total bacteria and $E$. coli was done 4 times in each treatment. Methods of calculating total bacteria and $E$. coli from the intestine were performed based on APHA procedure (2015).

\section{Statistic analysis}

Statistical analysis was performed by analysis of variance patterns Completely Randomized Design to compare between all treatments. Completely Randomized Design Factorial to compare between the extract and the powder form and between high, medium, and low doses. When variance analysis (ANOVA) is a significant difference between treatments at $\mathrm{P}<0.05$ then continued with LSD test.

\section{RESULTS AND DISCUSSION}

The effect of combining CAM, EM, and EDC extracts on the growth of $E$. coli and Salmonella sp.

The effect of combining plant extracts on the growth of E. coli and Salmonella sp is shown in Figures 2 and 3. A $100 \%$ concentration of the combination of CAM, EM, and EDC more effective inhibits the growth of E. coli bacteria compared to $50 \%$ and $25 \%$ concentrations and treatment of Zn-bacitracin antibiotics. This result indicated that the combination of bioactive substances 
with high concentrations wasvery potent in inhibiting $E$. coli growth compared to concentrations of $50 \%$ and $25 \%$. The concentration of a bioactive substance in medium (50\%) and low (25\%) was better inhibited the growth of E. coli and Salmonella sp than antibiotic zinc 2-methycardols 10-20\% (Saidu et al. 2012; Setianto et al. 2009; Kumar et al. 2002). P. niruri L plants contain saponins, tannins, phenols, glycosides, flavonoids, and terpenoids (Gbadamosi et al. 2015), and S. aromaticum plants containing eugenol (Perez-Jiménez et al. 2010). Many types of active compounds present on these three types of plants (CAM, EM, and EDC) may have a role in the destruction of membranes, cell walls, and even cell nuclei of bacteria so that bacteria are unable to reproduce and eventually die (Harborne 1987; Turgis et al. 2009).

CAM has potential as a Gram-positive antibacterial (Himejima \& Kubo 1991). The bioactive compound CNSL A. occidentale $\mathrm{L}$. is able to penetrate the bacterial lipid bilayer membrane (Parasa et al. 2011), thus destroying the membrane bilayer. The same thing occurs to $E$. coli that cause $E$. coli defense to the outer environment to decrease, so $E$. coli can not develop. Where in $E$. coli replication occurs every 20 minutes. The bioactive substance in CAM has the potential to inhibit the growth of $E$. coli so that the population declines.

The bioactive substances present in $P$. niruri $\mathrm{L}$ at various concentrations are able to inhibit $E$. coli growth by destroying the membrane structure (Monte et al. 2014; Gbadamosi et al. 2015). In vitro, at $60 \%$ concentration, no bacterial colonies of S. dysenteriae (Munfaati et al. 2015) were found. The concentration of $10 \mathrm{mg} / \mathrm{ml}$ inhibits $E$. coli growth with an inhibitory zone of up to $29 \mathrm{~mm}$ (Gbadamosi et al. 2015). The concentration of $P$. niruri extract $0.0313 \mathrm{~g} / \mathrm{ml}$ could inhibit the growth of Edwardsiella tarda bacteria (Sudarno et al. 2011). At concentrations of $1000 \mathrm{mg} / \mathrm{mL}$ also inhibited E. coli, Staphylococcus aureus, and Salmonella typhi (Ekwenye \& Njoku 2006). Water extract on $P$. niruri with a concentration of $0.75 \%$ can result in a $23 \mathrm{~mm}$ clear zone in $E$. coli (Lestariningsih et al. 2015).

Eugenol as the most dominant bioactive substance in S. aromaticum plant with water extract at $3 \%$ concentration able to inhibit the growth of E. coli, S. aureus and Bacillus cereus (Cortés-Rojas et al. 2014). $S$. aromaticum extract with ethanol fraction has $18 \mathrm{~mm}$ inhibition zone, while extract with methanol fraction has $20 \mathrm{~mm}$ clear zone to E. coli (Pandey \& Singh 2011). S. aromaticum extract at a concentration of 2000; 1500; and 1000 ppm showed each clear zone on E. coli about $13 \mathrm{~mm} ; 9 \mathrm{~mm}$, and $7 \mathrm{~mm}$, and at the same concentration showed clear zone on Salmonella typhi $23 \mathrm{~mm} ; 15 \mathrm{~mm}$; and $10 \mathrm{~mm}$ (Kumar et al. 2014). The results of this study indicated that the combination of bacitracin (recommended dose for AGP). Therefore, for a combination of bioactive substances at a dose of $25 \%$ is sufficient to replace AGP. Several studies have shown that A. occidental plants contain active compounds of anacardic acid, cardanol, cardols, CAM, EM, and EDC could inhibit the growth of E. coli and Salmonella sp.

Figure 1 showed that the bioactive substances CAM, EM, and EDC at the lowest concentration have responded to inhibit the growth of $E$. coli is stronger than Zn-bacitracin antibiotics dose 500 and $250 \mathrm{ppm}$. The ability of a combination of CAM, EM, and EDC to inhibit the growth of $E$. coli at a low concentration (25\%) match the ability of antibiotics. Therefore, in its application, the use of low concentrations can reduce the cost of bioactive substances.

Combinations of CAM, EM, and EDC with concentrations of $100 \%, 50 \%$, and $25 \%$ indicated inhibition of Salmonella sp growth were similar (Figure 2). Similarly, López et al. (2012) CAM on broilers inhibits Salmonella sp growth in the digestive tract. In the study of Sinurat et al. (2018) also reported that CAM may inhibit the growth of E. coli and Salmonella sp. Research on the use of liquid smoke from cashew shells against Salmonella sp has not been done extensively so that the information is still limited.

$P$. niruri L significantly decreased Salmonella sp population in spleens infected with Salmonella sp (Sunarmo 2009), At concentration 31.25-62.50 mg/mL $P$. niruri L extract also decreased Salmonella sp (Ekwenye \& Njoku 2006). Yusianti (2001) reported, in vitro use of $P$. niruri $L$ extract at $0.6 \%$ concentration was able to inhibit the growth of Salmonella pullorum. Besides being a resistor of bacterial growth, $P$. niruri $\mathrm{L}$ extract was expected to increase the resistance of livestock body, because it has a high antioxidant ability (Sinurat et al. 2018).

The bioactive substances commonly found in plants are polyphenols, diterpene, alkaloids, and flavonoids (Rao et al. 2004). The delayed growth of E. coli and Salmonella $s p$ is indicated because the bioactive substances of EM, CAM, and EDC are likely to form complexes with bacterial proteins through hydrogen bonds, consequently, the formation of nucleic acids and proteins in cells is inhibited. Turgis et al. (2009) stated that phenol (with-OH groups) can dissolve the lipids in the cell walls, thereby disrupting the cytoplasmic membrane performance and inhibit binding ATPase that cause cells to become lysis, as a result of bacterial growth is inhibited. Santoso (2008) reported, that the alkaloids contained in frangipani flowers (Plumeria acuminata) can suppress the growth of $S$. dysenteriae bacteria in vitro. From the results of in vitro assays, it is concluded that bioactive substances contained in the combination of EM, AM, and EDC are able to inhibit the total population of E. coli and Salmonella $s p$. 


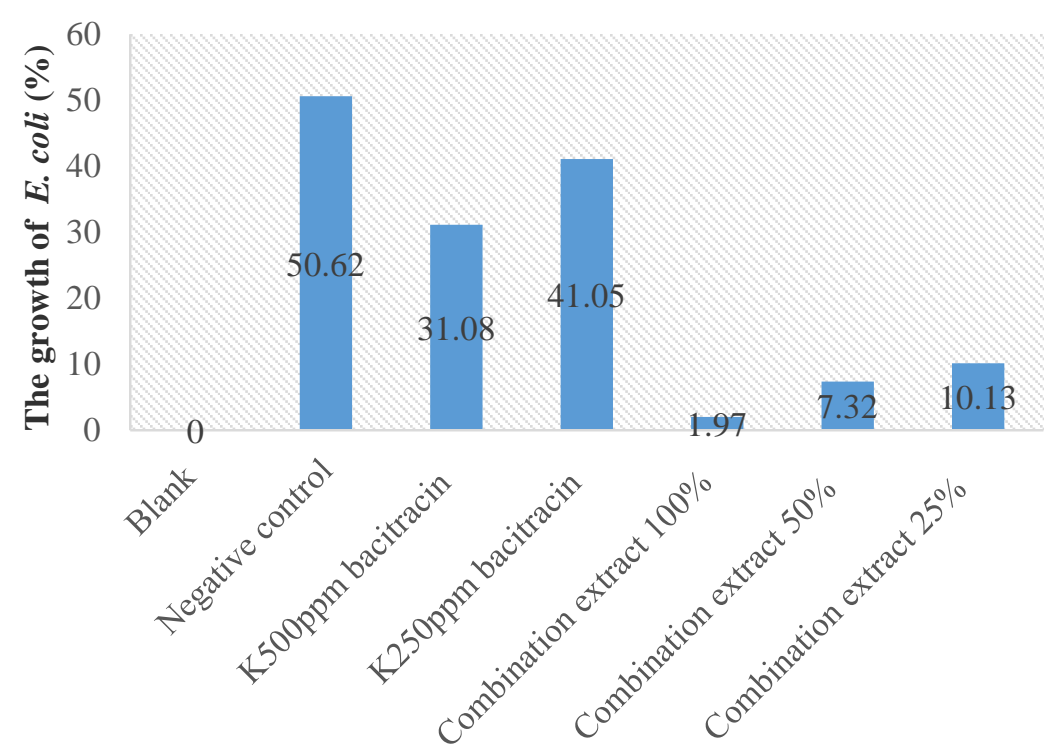

Combination of Plants Extract

Figure 1. The effect of combining EM, CAM, and EDC extracts on E. coli growth.

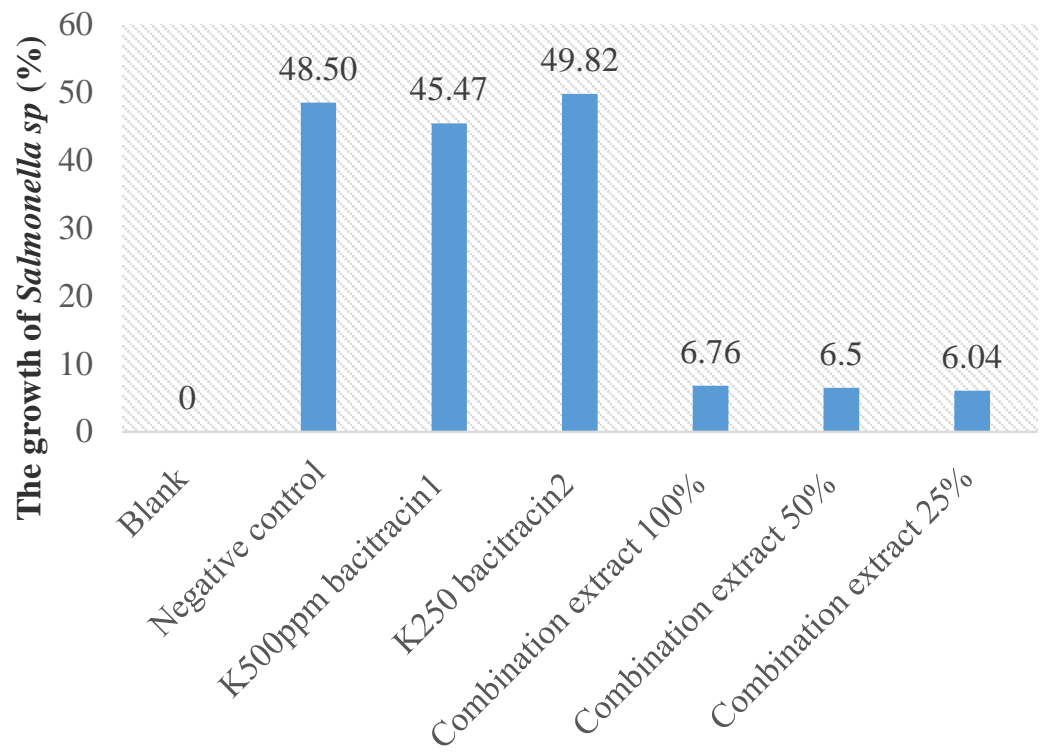

Plants Extract Combination

Figure 2. The effect of combining EM, CAM, and EDC extracts on Salmonella sp.

The effect of combination CAM, EM, and EDC on live weight, immune response, and blood profile

Body weight at the treatment of extract in medium and low dose, powder in high, moderate and low dose significantly $(\mathrm{P}<0.05)$ was significantly higher than negative control (Table 1). Combination of CAM, EM, and EDC in medium-dose at extract medium dose, powder in high, medium and low dose was not significantly different $(\mathrm{P}>0.05)$ with Zn-bacitracin treatment on live weight. But the treatment of medium and low dose extracts, high, medium and low-dose powder significantly $(\mathrm{P}<0.05)$ resulted in higher live weight than negative controls, which almost matched 
the antibiotic-fed chicken weight (Table 1 ). This result is only an early indication of the effect of the bioactive combination on chicken performance, since the number of tests and replication cattle used in this study is very limited. Tests using more numbers of livestock need to be done to determine the effect on livestock performance.

Giving combination CAM, EM, and EDC has the ability to replace antibiotics ( $\mathrm{Zn}$ bacitracin), it was shown from the weight of life did not differ between them, while chicken negative control treatment showed lower body weight than other treatments. Attia et al. (2017) reported that a mixture of thyme extract $400 \mathrm{~g}$, peppermint extract $300 \mathrm{~g}$, green tea extracts $200 \mathrm{~g}$, and licorice extract $100 \mathrm{~g}$ given to broiler chickens also showed improved performance compared to negative controls. The addition of a mixture of alfalfa leaf meal, cornflower, leaf senna and absinthe in broiler chicken feed also better than the control diet on enhances broiler growth (Khaligh et al. 2011). The mixture of some plants either in extract or flour form positively increases broiler weight, this also happens in combination CAM, EM, and EDC that can improve broiler performance. Bioactive substances of CAM such as phenol and anacardate act as antibacterials so that pathogenic bacteria in the intestine were eliminated and nutrients can be absorbed more optimally for growth needs. Khan (2010) reported that filantin, hypofilantin and flavonoids contained in EM act as a hepatoprotective agent (to prevent liver damage), thus metabolism in the liver such as protein synthesis for chicken growth is fulfilled. Giving eugenol as much as $100 \mathrm{mg} / \mathrm{kg}$ may improve the growth of chickens (Rychen et al. 2017). Likewise, eugenol contained in ED can increase chicken growth. Thus the combination of CAM, EM, ED has a positive synergistic effect on chicken performance.

\section{Immune responses in chickens by administering a combination of plant bioactive}

Statistical analysis of the relative weight of spleen and bursa fabricius and blood profile was not significant $(\mathrm{P}>0.05)$ between all treatments (Table 2). Spleen included in the secondary lymphoid functions to form granulocytes and erythrocytes. Relative spleen weights were not significantly different $(\mathrm{P}>0.05)$ among treatments, it was indicating the provision of a combination of CAM, EM, and ED at all doses did not affect the production of granulocytes, and erythrocytes in chickens. This indicates that when chickens are given a combination of CAM, EM, and EDC does not interfere with the production of granulocytes, and erythrocytes. Abdulkarimi (2011) reported that a single thyme administration did not affect the relative spleen weight. Giving mixed Echinacea purpurea, watercress, absinthe, and polygermander $10 \mathrm{~g}$ / kg in broiler chicken feed had no effect on the spleen relative weight (Khaligh 2011). This indicates that the provision of plant material on the chicken does not affect the size of the spleen.

Bursa fabricius as the primary lymphoid organ with the humoral immune system plays a role in the synthesis and secretion of antibody substances into the blood circulation. In the combination of CAM, EM, and EDC the weight of the fabrication stock was not significantly different ( $>0.05)$ with antibiotic treatment. The size of bursa fabricius affects the formation of antibodies, this indicates that the combination of CAM, EM, and EDC has a positive effect on antibody formation. Table 2 shows that although the relative weight of the bursa fabricius was not significant $(\mathrm{P}<0.05)$ between treatments, the combination of high and low powder produced a higher weight than antibiotic treatment. Likewise, Khaligh et al. (2011) reported that administration of a mixture of thyme extract $400 \mathrm{~g}$, peppermint extract $300 \mathrm{~g}$, green tea extract $200 \mathrm{~g}$ and licorice extract $100 \mathrm{~g}$ in broiler chickens showed the relative weight of the bursa fabricius there was no difference between both of them. Similarly, the administration of single thyme through drinking water does not show a difference with control (Abdulkarimi 2011).

\section{Blood profile}

The number of hematocrits, hemoglobin, lymphocytes, monocytes, and basophils were not significantly different $(\mathrm{P}>0.05)$ among all treatments (Table 2). This indicates that administration of a combination of CAM, EM, and EDC as a substitute for antibiotics do not interfere with the synthesis of hematocrit, hemoglobin, lymphocytes, monocytes, and basophils. Overall that antibiotic and bioactive combination treatments have no significant effect on the immune system. This can be seen from the size of the organ weight that does not affect the immune system. In fact, in vitro, the bioactive combination tested contained ingredients with a high antioxidant ability of $P$. niruri L, as reported by Sinurat et al. (2018). This is likely because the chickens that are raised are not challenged against diseases or bacteria.

\section{Effect of the combination of CAM, EM, and EDC on total bacteria and number of Escherichia coli in the ileum}

The combination of CAM, EM, and EDC in broiler chickens in the form of extracts or powder was not significantly different $(\mathrm{P}>0.05)$ against total bacteria and the number of $\mathrm{E}$. coli in the ileum. However, with 
Table 2. Effect of the combination of CAM, EM and EDC on life weight, the relative weight of spleen and bursa fabricius, and blood profile

\begin{tabular}{|c|c|c|c|c|c|c|c|c|}
\hline \multirow[t]{2}{*}{$\begin{array}{l}\text { Bioactive form } \\
\text { and dosage }\end{array}$} & \multirow[t]{2}{*}{$\begin{array}{c}\text { Life } \\
\text { weight, g }\end{array}$} & $\begin{array}{l}\text { Spleen } \\
\text { weight }\end{array}$ & $\begin{array}{c}\text { Bursa } \\
\text { fabrisius } \\
\text { weight }\end{array}$ & \multirow{2}{*}{$\begin{array}{c}\text { Hematocrit/ } \\
\text { PVC } \\
(\%)\end{array}$} & \multirow[t]{2}{*}{$\begin{array}{l}\text { Hemoglobin } \\
\text { (g/dl) }\end{array}$} & \multirow[t]{2}{*}{$\begin{array}{c}\text { Lymphocytes } \\
\text { (\%) }\end{array}$} & \multirow[t]{2}{*}{$\begin{array}{c}\text { Monocytes } \\
\text { (\%) }\end{array}$} & \multirow[t]{2}{*}{$\begin{array}{c}\text { Basophils } \\
\text { (\%) }\end{array}$} \\
\hline & & \multicolumn{2}{|c|}{ (\% Life weight) } & & & & & \\
\hline \multicolumn{9}{|l|}{ Extract form: } \\
\hline High dose & $750.3^{\mathrm{dc}}$ & 0.138 & 0.098 & 18.00 & 8.25 & 67.50 & 26.5 & 1.5 \\
\hline Medium dose & $905.5^{\mathrm{ab}}$ & 0.103 & 0.118 & 15.75 & 5.45 & 71.75 & 20 & 0 \\
\hline Low dose & $806.8^{\text {bcd }}$ & 0.155 & 0.118 & 22.50 & 10.88 & 71.50 & 26.5 & 1.75 \\
\hline \multicolumn{9}{|l|}{ Powder form } \\
\hline High dose & $828.8^{\mathrm{abc}}$ & 0.098 & 0.180 & 20.00 & 5.45 & 77.00 & 18.5 & 0.75 \\
\hline Medium dose & $818.0^{\mathrm{abc}}$ & 0.113 & 0.083 & 17.75 & 9.75 & 73.75 & 21.25 & 0.5 \\
\hline Low dose & $927.8^{\mathrm{ab}}$ & 0.085 & 0.195 & 23.75 & 10.50 & 69.75 & 30.25 & 0.5 \\
\hline Zn-Bacitracin & $940.3^{\mathrm{a}}$ & 0.103 & 0.163 & 16.00 & 4.00 & 60.50 & 14.5 & 0 \\
\hline Negative control & $682.0^{\mathrm{d}}$ & 0.073 & 0.090 & 20.25 & 10.45 & 74.25 & 18 & 0 \\
\hline Significance (P) & 0.006 & 0.25 & 0.26 & 0.85 & 0.16 & 0.88 & 0.6395 & 0.6788 \\
\hline
\end{tabular}

Description: Different subscripts in different lanes show significant differences $(\mathrm{P}<0.05)$

the medium dose of extract treatment showed the total bacteria was lower than Zn-bacitracin treatment, this indicates that the combination of CAM, EM, and ED in medium dose can replace antibiotics. Likewise, the number of $E$. coli is still lower than the control which indicates that the combination treatment of CAM, EM, and ED can replace Zn-Bacitracin (Table 3).

The use of herb extracts as natural medicine has long been practised as an antimicrobial in the intestinal ecosystem to increase feed digestibility (Hernández et al. 2004). Attia et al. (2017) reported giving a mixture of oregano, fenugreek, chamomile and fennel extract reduced coliform bacteria and $E$. coli. The single administration of essential oil of $C$. xanthorrhiza or lemon peel did not affect the total bacteria in the ileum and cecum of broiler (Akbarian et al. 2013).

\section{Effect of form and dose combination of CAM, EM, and EDC on total bacteria and number of $E$. coli}

Treatment of combination of CAM, EM, EDC in broiler chickens between extract and powder form in high, medium, and low concentration was not significantly different $(\mathrm{P}>0.05)$ with Zn-Bacitracin treatment on total bacteria and the number of $E$. coli in the ileum (Table 4). This indicates that bioactive substances of three combinations (CAM, EM, EDC) have the same ability as Zn-Bacitracin as an antibacterial.

Himejima \& Kubo (1991) reported that CAM had the ability to kill Gram-positive bacteria, where the bioactive compound of CNSL Anacardium occidentale L. was able to penetrate the membrane of bacterial lipid bilayers (Parasa et al. 2011), thus damaging its layer. The same thing happened to $E$. coli as described earlier that the defense of $E$. coli against the external environment decreases due to damage to cell walls by bioactive substances so that $E$. coli in the ileum cannot develop.

While the bioactive substances contained in $P$. niruri L) such as alkaloids saponins, tannins, phenols, glycosides can inhibit the growth of $E$. coli by damaging the membrane structure (Monte et al. 2014; Gbadamosi et al. 2015). Reportedly, P. niruri L extract at various concentrations can inhibit bacterial growth. The use of $P$. niruri L extract in vitro at a concentration

Table 3. Effect of the combination of CAM, EM, EDC on total bacteria and number of E. coli in vivo

\begin{tabular}{lcc}
\hline \hline Form and dose & $\begin{array}{c}\text { Bacteria total } \\
(\log \mathrm{cfu} / \mathrm{ml})\end{array}$ & $\begin{array}{c}\text { Escherichia coli } \\
(\log \mathrm{cfu} / \mathrm{ml})\end{array}$ \\
\hline Extract: & 4.6775 & 2.677 \\
High dose & 3.3150 & 2.773 \\
Medium dose & 4.9550 & 3.935 \\
$\quad$ Low dose & & \\
Powder: & 4.2350 & 2.657 \\
High dose & 4.2600 & 1.917 \\
Medium dose & 5.2325 & 3.120 \\
Low dose & 4.8575 & 0.954 \\
Zn-Bacitracin & 4.9200 & 4.673 \\
Negative control & & \\
\hline
\end{tabular}


of $60 \%$ resulted in no visible growth of $S$. dysenteriae colonies (Munfaati et al. 2015), at the concentration of $10 \mathrm{mg} / \mathrm{ml}$ inhibited $E$. coli growth with inhibitory zones of up to $29 \mathrm{~mm}$ (Gbadamosi et al. 2015). P. niruri L. extract $0.0313 \mathrm{~g} / \mathrm{ml}$ can inhibit the growth of Edwardsiella tarda bacteria (Sudarno et al. 2011), at concentrations of $1000 \mathrm{mg} / \mathrm{mL}$ also inhibit E. coli, Staphylococcus aureus, and Salmonella typhi (Ekwenye \& Njoku 2006). P. niruri L. extract with a water fraction at a concentration of $0.75 \%$ can produce a 23 $\mathrm{mm}$ inhibition zone in $E$. coli in vitro (Lestariningsih et al. 2015).

Administration of Meniran ( $P$. niruri L) extracts 1 $\mathrm{ml} / \mathrm{kg}$ BW on broiler chicken that infected with Mycoplasma gallisepticum or CRD can improve the performance (Hidanah et al. 2017). As is known in previous in vitro studies that the treatment of the combination of CAM, EM, EDC extract can reduce the population of E. coli. The data above shows that administration of $P$. niruri L. plants in either extract or powder forms has the ability to eliminate $E$. coli populations in vitro and in vivo (in the digestive tract).

Eugenol as the most dominant bioactive substance in Syzygium aromaticum plants, with water extract at a concentration of $3 \%$ can inhibit the growth of E. coli, Staphylococcus aureus and Bacillus cereus (CortésRojas et al. 2014). S. aromaticum extract with ethanol fraction had an $18 \mathrm{~mm}$ inhibition zone, with the methanol fraction having a $20 \mathrm{~mm}$ inhibition zone against E. coli (Pandey \& Singh 2011). S. aromaticum extract at a concentration of $2000 \mathrm{ppm}$ showed a $13 \mathrm{~mm}$ inhibition zone, $1500 \mathrm{ppm}$ with a 9mm inhibition zone, and $1000 \mathrm{ppm}$ with a $7 \mathrm{~mm}$ inhibition zone against $E$. coli (Kumar et al. 2014). The same thing can be seen in this study, that the lower the concentration of bioactive substances, the lower the inhibitory power.

The ability of each bioactive substance from the three plants, after being combined at moderate doses is the best for eliminating the population of E. coli in the chicken's digestive tract.

\section{Effect of form and dosage of plant combinations on life weight, immune response, and blood profile.}

Combination of CAM, EM, and EDC in broiler chickens in the form of extracts and powder in high, medium and low doses did not have a significant effect $(\mathrm{P}>0.05)$ on life weight, spleen weight, weight of the fabric, and blood profile, but real $(\mathrm{P}<0.05)$ against (Table 5). Statistically, the combination of CAM, EM, and ED does not affect the amount of hematocrit, production of macrophage and erythrocytes by spleen, does not affect the synthesis of antibodies by lymphocytes in the bursa fabicius. This illustrates that chickens are not lacked water, just as the process of transporting oxygen is not disturbed because hemoglobin synthesis is not disturbed. Monocytes that play a role in the immune system and basophil which is known to have the function of forming antibodies to react to allergies are also not affected by the combination treatment of CAM, EM, and EDC in broiler chickens.

Table 4. Effect of the form and dosage of the combination of CAM, EM, and EDC on total bacteria and the number of $E$. coli in the ileum

\begin{tabular}{lcc}
\hline \hline $\begin{array}{l}\text { Form and } \\
\text { concentration }\end{array}$ & $\begin{array}{c}\text { Bacteria total } \\
\text { (CFU/g) }\end{array}$ & $\begin{array}{c}\text { Escherichia coli } \\
\text { (CFU/g) }\end{array}$ \\
\hline Form: & & \\
Extract & 4.7082 & 0.1327 \\
Powder & 4.5758 & 0.1180 \\
Significance (P) & 0.77 & 0.1135 \\
Concentration: & & \\
$\quad$ High & 4.4563 & $0.1343^{\mathrm{a}}$ \\
$\quad$ Medium & 4.3286 & $0.1075^{\mathrm{b}}$ \\
$\quad$ Low & 5.0938 & $0.1371^{\mathrm{a}}$ \\
$\quad$ Significance (P) & 0.3309 & 0.0092 \\
Form*Concentration & 0.61 & 0.04 \\
\hline
\end{tabular}

a, b In different lanes shows significant differences $(\mathrm{P}<0.05)$

Table 5. Effect of forms and doses combination of CAM, EM, EDC on live weight, spleen, bursa fabricius, and blood profile

\begin{tabular}{|c|c|c|c|c|c|c|c|c|}
\hline $\begin{array}{l}\text { Form and } \\
\text { concentration }\end{array}$ & $\begin{array}{c}\text { Life } \\
\text { weight (g) }\end{array}$ & $\begin{array}{c}\text { Spleen } \\
\text { (\%) }\end{array}$ & $\begin{array}{c}\text { Bursa } \\
\text { Fabricius (\%) }\end{array}$ & $\begin{array}{c}\text { Hematocrit } \\
(\%)\end{array}$ & $\begin{array}{l}\text { Hemoglobin } \\
\text { (g/dl) }\end{array}$ & $\begin{array}{c}\text { Lymphocytes } \\
\text { (\%) }\end{array}$ & $\begin{array}{c}\text { Monocytes } \\
\text { (\%) }\end{array}$ & Basophils (\%) \\
\hline \multicolumn{9}{|l|}{ Form: } \\
\hline Extract & 820.8 & 3.13 & 0.15 & 22.50 & 10.92 & 70.3 & 29.20 & 4.33 \\
\hline Powder & 858.2 & 2.57 & 0.17 & 22.36 & 10.28 & 73.5 & 28.00 & 1.75 \\
\hline \multicolumn{9}{|l|}{ Concentration: } \\
\hline High & 789.5 & 2.67 & 0.16 & 21.71 & 10.96 & 72.25 & 30.00 & 3.00 \\
\hline Medium & 861.8 & 2.35 & 0.14 & 22.33 & 10.13 & 72.75 & 28.38 & 2.00 \\
\hline Low & 867.3 & 3.53 & 0.18 & 23.13 & 10.69 & 70.63 & 27.50 & 3.00 \\
\hline
\end{tabular}




\section{CONCLUSION}

The combination of cashew shell liquid of Anacardium officinale (CAM), Phyllanthus niruri L. (EM) extract, and clove leaf extract (EDC) can inhibit the growth of Escherichia coli and Salmonella sp. The best dose combination extract in inhibiting the growth of E. coli and Salmonella sp. is $100 \%$, but the $25 \%$ dose has matched the AGP in vitro. In biological tests, a combination of CAM, EM, and EDC in the form of extracts with high, medium or low doses did not affect spleen weight, bursa fabricius, and blood profile. The best combination of CAM, EM, and EDC in the form of extracts or powder that reduces the total population of bacteria and the population of E. coli in the chicken intestine is a moderate dose. Likewise, for weight gain, there are indications that medium doses of extracts or powder can replace antibiotics. So it is concluded that the combination of CAM, EM, and EDC has the potential to replace AGP in poultry feed, especially on chicken.

\section{ACKNOWLEDGMENT}

The authors appreciate the technicians who provided the extracts productions and helped the laboratorium experiment, Rita and Dewi. The project was funded by Anggaran Pendapatan dan Belanja Negara (APBN).

\section{REFERENCES}

Abdulkarimi R. 2011. Immune response of broiler chickens supplemented with Thyme exteract (Thymus vulgaris) in drinking water. Ann Biol Res. 2:208-212.

[APHA] American Public Health Association. 2015. Compendium of methods for the microbiological examination of foods. Yvonne Salfinger Y, Tortorello ML, editors. 5th ed. Washington DC (USA): APHA Press.

Akbarian A, Golian A, Kermanshahi H, Farhoosh R, Raji AR, De Smet S, Michiels J. 2013. Growth performance and gut health parameters of finishing broilers supplemented with plant extracts and exposed to daily increased temperature. Span J Agric Res. 11:109-119.

Attia G, Hassanein E, El-Eraky W, El-Gamal M, Farahat M, Hernandez-Santana A. 2017. Effect of dietary supplementation with a plant extract blend on the growth performance, lipid profile, immune response and carcass traits of broiler chickens. IJPS. 16:248-256.

Barton MD, Hart WS. 2000. Public health risks: Antibiotic resistance - A Review. Asian-Aust J Anim Sci. 14:414422.

Bintang IAK, Sinurat AP, Purwadaria T. 2007. Penambahan ampas mengkudu sebagai senyawa bioaktif terhadap performans ayam broiler. JITV. 12:1-5.
Bridgwater AV. 2004. Biomass fast pyrolysis. Thermal Sci. 8:21-49.

Butaye P, Devriese LA, Haesebrouck F.2003. Antimicrobial growth promoters used in animal feed: effects of less well known antibiotics on gram-positive bacteria. Clin Microbiol Rev. 16:175-188.

Cortés-Rojas DF, Fernandes de Souza CR, Oliveira WP. 2014. Clove (Syzygium aromaticum): A precious spice. Asian Pac J Trop Biomed. 4:90-96.

Ekwenye UN, Njoku NU. 2006. Antibacterial effect of Phylanthus niruri (Chanca Piedra) on three enteropatogen in Man. Int J Mol Medic Adv Sci. 2:184189.

Griggs JP, Jacob JP. 2005. Alternatives to antibiotics for organic poultry production. J Appl Poult Res. 14:750756.

Gbadamosi IT. 2015. Antibacterial attributes of extracts of Phyllantus amarus and Phyllantus niruri on Escherichia coli the causal organism of urinary tract infection. J Pharm Phytoth. 7:80-86.

Hernández F, Madrid J, García V, Orengo J, Megías MD, 2004. Influence of two plant extracts on broilers performance, digestibility, and digestive organ size. Poult Sci. 83:169-174.

Hidanah S, Sabdoningrum EK, Wahjuni RS, Arimbi. 2017. Implementation of meniran extract (Phyllanthus niruri Linn) on the performance of broiler chickens infected by Mycoplasma gallisepticum caused Chronic Respiratory Disease. Vet Medic Int Conf. 2017:296307.

Himejima M, Kubo I. 1991. Antibacterial agent from thecashew Anacardium occidentale (Anacardiaceae) nut shell oil. J Agric Food Chem. 39:418-421.

Hoque M, Inatsu M, Juneja V, Kawamoto, S. 2007. Antimicrobial activity of cloves and cinnamon extracts against food borne pathogens and spoilage bacteria and inactivation of Listeria monocytogenes in ground chicken meat with their essential oils. J Food Sci Technol. 72:9-21.

Khaligh F, Sadeghi G, Karimi A, Vaziry A. 2011. Evaluation of different medicinal plants blends in diets for broiler chickens. J Medic Plants Res. 5:1971-1977.

Kubo I, Komatzu S, Ochim M. 1986. Molluscicides from the Cashew Anacardium occidentale and their large-scale isolation. J Agric Food Chem. 34:970-973.

Kumar PP, Paramashivappa R., Vithayathil PJ, Rao PVS, Rao AS. 2002. Process for isolation of cardanol from technical cashew (Anacardium occidentale) nut shell liquid. J Agric Food Chem. 50:4705-4708.

Kumar Y, Agarwal S, Srivastava A, Kumar S, Agarwal G, Khan MZA. 2014. Antibacterial activity of Clove (Syzygium aromaticum) and Garlic (Allium sativum) on different pathogenic bacteria. Int J Pure App Biosci. 2:305-311. 
Lestariningsih, Sjofjan O, Sudjarwo E. 2015. Pengaruh tepung tanaman meniran terhadap aktivitas antimikroba bakteri asam laktat dan Escherichia coli. J Ilmu-ilmu Peternakan. 25:55-60.

López CAA, Lima KRS, Manno MC, Tavares FB, Fernandes Neto DL, Jesus MLC, Viana MAO, Fonseca LAB. 2012. Effects of cashew nut shell liquid (CNSL) on the performance of broiler chickens. Arq Bras Med Vet Zootec. 64:1027-1035.

Monte J, Abreu AC, Borges A, Simões LC, Simões M. 2014 Antimicrobial activity of selected phytochemicals against Escherichia coli and Staphylococcus aureus and their biofilms. Pathogens. 3:473-498.

Munfaati PN, Ratnasari E, Trimulyono G. 2015. Aktivitas senyawa antibakteri ekstrak herba meniran (Phyllanthus niruri) terhadap pertumbuhan bakteri Shigella dysenteriae secara in vitro. Lentera Bio. 4:64-71.

Natsir MH, Hartutik, Sjofjan O, Widodo E. 2013. Effect of either powder or encapsulated form of garlic and Phyllanthus niruri L. mixture on broiler performances, intestinal characteristics and intestinal microflora. IJPS. 12:676-680.

Noor SM, Poeloengan M. 2005. Pemakaian antibiotika pada ternak dan dampaknya pada kesehatan manusia. Lokakarya Nasional Keamanan Pangan Produk Peternakan. p. 56-64.

Oyedemi SO, Okoh AI, Mabinya LV, Pirochenva G, Afolayan AJ. 2009. The proposed mechanism of bactericidal action of eugenol, $\alpha$-terpineol and $\gamma$-terpinene against Listeria monocytogenes, Streptococcus pyogenes, Proteus vulgaris and Escherichia coli. Afr J Biotechnol. 8:1280-1286.

Pandey A, Singh P. 2011. Antibacterial activity of Syzygium aromaticum (clove) with metal ion effect against food borne pathogens. Asian J Plant Sci Res. 1:69-80.

Parasa LS, Tumati SR, Kumar LCA, Chigurupati SP, Rao GS. 2011. In Vitro-antimicrobial activity of cashew (Anacardium occidentale L.) nuts shell liquid against methicillin resistant Staphylococcus aureus (MRSA) clinical isolates. Int J Pharm Pharm Sci. 3:436-440.

Petersen KJ, Muretta JM, Higgins SE, Peterson KC, Gillipie GD, et al. 2014. High throughput time resolved flourescence in a microplate reader. Biophysical J 106:205-206.

Putri N. 2002. Uji efektifitas dan jenis daun tanaman terhadap perkembangan penyakit antraknosa dosebabkan oleh jamur Colletotricum capsici (Syd) pada buah cabai pasca panen. [Padang (Indones)]: Universitas Andalas.

Rao YK, Vimalamma G, Rao CV, Tzeng YM. 2004. Flavonoids and andrographolides from Andrographis paniculata. Phytochemistry. 65:2317-2321.

Rychen G, Aquilina G, Azimonti G, Bampidis V, Bastos ML, et al. 2017. Efficacy of Liderfeed ${ }^{\circledR}$ (eugenol) for chickens for fattening. EFSA J. 15:1-2.
Saenab A, Wiryawan KG, Retnani Y, Wina E. 2016. Karakteristik fisik dan kimia dari produk bioindustri cangkang Jambu mete (Anacardium occidentale). J Littri. 22:35-41.

Saidu AN, Akanya HO, Dauda BEN, Ogbadoyi EO. 2012. Antibacterial and comparative hypoglycemic effect of Anacardium occidentale leaves. Int Res J Biochem Bioinform. 2:6-10.

Santoso AT, Sidharta B, Noorhamdani, 2008. Uji ekstrak bunga kamboja (Plumeria acuminatae) sebagai antimikroba terhadap Shigella dysenteriae secara in vitro (not published). [Malang (Indones)]: Universitas Brawijaya.

Setianto WB, Yoshikawa S, Smith RL, Jr, Inomata $\mathrm{H}$, Florusse LJ, Peters CJ. 2009. Pressure profile separation of phenolic liquid compounds from cashew (Anacardium occidentale) shell with supercritical carbon dioxide and aspects of its phase equilibria. J Supercrit Fluids. 48:203-210.

Setyohadi R, Abdullah AAHA, Narwastu ACLK, 2011. Uji efektifitas antibakteri ekstrak meniran (Phyllanthus niruri) terhadap Streptococcus pyogenes secara In Vitro. (not published). [Malang (Indones)]: Universitas Brawijaya.

Sinurat AP, Purwadaria T, Pasaribu T, Susana IWR, Dharma J, Rosida J, Sitompul S, Udjianto. 2004. Efektifitas bioaktif lidah buaya sebagai imbuhan pakan untuk ayam broiler yang diperoleh di atas litter JITV. 9:145-150.

Sinurat AP, Purwadaria T, Bintang IAK, Ketaren PP, Bermawie N, Raharjo M, Rizal M. 2009. Pemanfatan kunyit dan temulawak sebagai imbuhan pakan untuk ayam broiler. JITV. 14:90-96.

Sinurat AP, Wina E, Rakhmani SIW, Wardhani T, Haryati T, Purwadaria T. 2018. Bioactive substances of some herbals and their effectiveness as antioxidant, antibacterial, and antifungi. JITV. 23:18-27.

[SPI] Statistik Perkebunan Indonesia 2014-2016. 2015. Jambu mete (Cahew Nut). Subiyantoro ME, Arianto Y, editors. Jakarta (Indones): Direktorat Jenderal Perkebunan, Kementerian Pertanian.

Sudarno, Setiorini FA, Suprapto H. 2011. Efektifitas ekstrak tanaman meniran (Phyllanthus niruri) sebagai antibakteri Edwardsiella tarda secara in vitro. 3:103108.

Turgis M, Han J, Millette M, Salmieri S, Borsa J, Lacroix M. 2009. Effect of selected antimicrobial compounds on the radio sensitization of Salmonella typhi in ground beef. Letters App Microbiol. 48:657-662.

Yusianti TS. 2001. Daya antibacterian ekstrak tanaman meniran (Phylanthus niruri L.) dibandingkan oksitetrasiklin terhadap Salmonella pullorum secara in vitro (Script). [Surabaya (Indones)]: Universitas Airlangga. 